This is an author produced version of a paper published in Mortality: Promoting the interdisciplinary study of death and dying. This paper has been peer-reviewed but may not include the final publisher proof-corrections or pagination.

Citation for the published paper:

Petersson, Anna \& Wingren, Carola. (2011) Designing a memorial place: continuing care, passage landscapes and future memories. Mortality: Promoting the interdisciplinary study of death and dying. Volume: 16, Number: 1, pp 54-69.

http://dx.doi.org/10.1080/13576275.2011.536369.

Access to the published version may require journal subscription. Published with permission from: Routledge.

Epsilon Open Archive http://epsilon.slu.se 
Designing a Memorial Place:

Continuing Care, Passage Landscapes and Future Memories

Anna Petersson and Carola Wingren

\section{About the Authors}

Anna Petersson is a PhD-student at the Department of Architecture and Built Environment, Lund University, Sweden. She has a Master of Fine Arts in Design and a Licentiate degree in Theoretical and Applied Aesthetics.

Anna Petersson (corresponding author)

Theoretical and Applied Aesthetics

Department of Architecture and Built Environment

Faculty of Engineering, LTH, Lund University

P.O. Box 124

22100 Lund, Sweden

anna.petersson@arkitektur.lth.se

+46707452988

Carola Wingren is a Professor of Theoretical and Applied Aesthetics at the

Department of Landscape Architecture, Swedish University of Agricultural Sciences. She has a PhD in Landscape Planning and a twenty-year long professional career as a practicing landscape architect.

Carola Wingren

Landscape Planning, Horticulture and Agricultural Science

Department of Landscape Architecture

Swedish University of Agricultural Sciences

P.O. Box 58, Sundsvägen 4-6

23053 Alnarp, Sweden.

carola.wingren@ltj.slu.se

+4640415161

Abbreviated title:

Designing a Memorial Place 


\title{
Designing a Memorial Place: \\ Continuing Care, Passage Landscapes and Future Memories
}

\author{
(Received $X X$; final version received $X X$ )
}

\begin{abstract}
The design and selection of a memorial stone and gravesite that represent the deceased is a central issue for people bereaved by traffic accidents. This was revealed in an interview survey of recent Swedish roadside memorials and other memorial places. This text will look at this design and selection as expressions of continuing care for the deceased and as a way to find comfort for the bereaved. Materiality, representation and presence will be discussed as crucial parts of the link between the living and the dead. Communicative, spatial and physical values are important also in the professional's design of common public memorial places. Of specific interest for this text are two design practice based terms, memory object and passage landscape, which may be used by landscape architects when designing memorial places, such as cemeteries and public monuments. Throughout this text, we will hold memorial places like these as capable of bridging the gap between the space of life and the space of death as well as supporting the regeneration of present memories and the construction of future ones.
\end{abstract}

Keywords: continuing care; memorialisation; design; presence; place; passage landscape

\section{Introduction}

It took a long time before the gravestone of the husband and father that died in a motor vehicle accident was erected. The stone is made of granite, quarried in the county where the deceased was born. 'We knew exactly, we looked around a lot. [The gravestone] is not polished, it is quite rough. [...] He was a rather rough person. Yes, genuine', says the wife of the departed. 'The grandchildren wanted it to be polished with golden text, but I said he wasn’t like that, your grandfather. And they agreed'.

The story above, taken from an interview survey of recent Swedish roadside memorials and other memorial places (Petersson, 2009a; 2009b; 2010), is but one example of the importance of letting the design and material of the gravestone, as well as the location and scenery of the site of the grave, represent the deceased's origin, personality and personal preferences. This article will look at this practice as an expression of continuing care for the deceased and as a way to find comfort for the bereaved (Bachelor, 2004; Aggedal, 2006). In the following extension of this 
discussion, materiality, representation and presence will be held as crucial parts of the continuing link between the living and the dead (Gibson, 2004; Francis et al., 2005).

Communicative, spatial and physical values are important also in the professional’s design of common public memorial places (Foote, [1997] 2003; Hunt, 2001). We will in this text present two terms, memory object and passage landscape, developed over years of professional practice in landscape architecture and in an academic doctoral thesis (Wingren, 2002; 2009), which may be applied by landscape architects when constructing a public memorial place. In order to illustrate a complex passage landscape with powerful memory objects we will more closely examine the design process and selection of the site for the public monument at Backaplan, inaugurated in 2008 in remembrance of the sixty-three young people who died in a fire at a dance club in Gothenburg, Sweden in 1998. Throughout this article we will recognise memorial places, such as the individual grave in the cemetery as well a common public monument, as commemorative passage landscapes, bridging the gap between the space of life and the space of death as well as supporting the regeneration of present memories and the construction of future ones.

\section{Choosing and Designing the Memorial Stone and Gravesite}

The design of graves and the messages inscribed on them have throughout history told where and when a person was born and died, the cause of death, the deceased's profession and family status, and social, economic and religious affiliation (see, for instance: Hagberg, 1937, pp. 477-91; Lindahl, 1969; Andersson, 2004). New ways of dealing with the loss of loved ones leave continuous traces in the landscapes of death, from the churchyard as the sacred heart of the city (Ariés, [1976] 1994, pp. 69-76) to 
extra-urban cemeteries (Etlin, 1984, pp. 163-366) and, more recently, to the interment of ashes outside the borders of the cemetery in a setting specific to the deceased (Dahlgren \& Hermansson, 2003). Some researchers even speak of a shift from an institutional to an individual notion of death (Walter, 1994, pp. 16-25), one that leaves its marks on the expression and material form of cemeteries and memorials as well as funerals.

During the last twenty years the memorial stones and grave decorations in Swedish cemeteries have become increasingly individualized, symbolically displaying feelings, thoughts and ideas of our time (Gustavsson, 2003) [1]. As Reimers (1999) notes, cemeteries, tombstones and funerals may also be seen as cultural communication and symbolic actions for the construction of ethnic and cultural identity in the multicultural Swedish cemetery of today (see also: Larsson, 2009).

In a study of peoples’ conception of recent Swedish roadside memorials and other memorial places, the design of the memorial stone and selection of the gravesite stand out as central for people who unexpectedly had lost a child or a spouse in a traffic accident. A related issue was the importance to these bereaved of making the funeral ceremony and the choice of things to place in the open casket when saying goodbye confirm the deceased's private, personal and social persona (see also: Reimers, 1999; Gustafsson, 2003; Aggedal, 2006).

The above-mentioned interview survey was carried out in 2005 as part of Petersson's ongoing $\mathrm{PhD}$ project. Its focus is on the qualitative differences between some strategically chosen interviewees' conceptions and experiences of roadside memorials in Sweden. The aim of the interview study was to learn when, how and why roadside memorials emerge and what they mean to different people (Petersson, 2009a; 2010) [2]. 
In order to encourage various viewpoints of roadside memorialisation the study includes interviews with: six relatives from different families bereaved by traffic accidents; four taxi drivers (of which one was a former lorry driver); one commercial traveller; three employees at the Swedish Road Administration; and two employees at the Swedish Union of Transportation (of which one was a former lorry driver). The reason for choosing mentioned interviewees was firstly their supposed contact with and experience of roadside memorialisation and secondly their different life and work situations, as close relatives of traffic victims or as coming from the particular professions mentioned, which were presumed to affect their conceptions of roadside memorials (Petersson, 2010) [3].

The interviewees' conceptions of roadside memorials were in Petersson's interviews related to their experiences of other memorial places, such as churchyards and cemeteries, home memorials, other places and things connected to personal memories of the deceased, and public funeral monuments (Petersson 2009b; 2010). One of the topics was the design of the memorial stone and choice of the location for the gravesite in the cemetery or churchyard. The data used in this text concerns question on the design and location of the gravesite taken from the interview responses from people bereaved by traffic accidents [4]. This since in the group of interviewees that had lost a child or a spouse in a traffic accident the interview responses concerning the design of the memorial stone and gravesite were more concerned than the other interviewees about the expression and location of the memorial within in the cemetery. 


\section{Expressing Something About the Deceased: Identity, Care and Comfort}

Even though it is not possible to compare one person's grief to another, as one of the respondents in Petersson's study so thoughtfully put it, there are some differences between the interviewed persons in the study worth pointing out here. One difference is that among those bereaved by traffic accidents, five out of six had lost a child and the sixth her husband, while the other interviewees had lost relatives at the more advanced age of a parent or grandparent [5]. Another variation is the difference between a 'bad' death, such as sudden and unexpected death, as opposed to the 'good' death that comes with old age or follows long-term illness [6].

Studies show that memorial stones for children and adolescents tend to display more personal and emotional motives and messages than stones for middle-aged or elderly people (Gustavsson, 2003, pp. 23-4; Francis et al., 2005, pp. 172-7). In the same way, burials tend to become more elaborate and personal when the deceased is young or the death was unexpected and sudden (Åkesson, 1997, p. 126).

The subjects in Petersson's study that had unexpectedly lost a child or spouse in a traffic accident felt that, by making the gravesite and memorial stone reflect the deceased's personality and personal preferences, they could in some way ensure that other people knew something about the deceased. Generally, these bereaved people were able to design the memorial stone and the gravesite according to their own wishes within the rules and regulations of each specific grave quarter and cemetery or churchyard (Begravningslag, 1990:1144, §§ 25-9). For some of the bereaved interviewed this included expressing the absence of future memories of the departed. As an example, one bereaved father described the memorial stone for his son, which was designed by the boy's mother and placed in a nineteen century churchyard, in these words: 
And it is a bit symbolic, so the middle stone is finished while the stones around it are slightly rougher cut. This [part] that is finished a bit, that is the part that is done in [my son's] life, what he has been through and experienced, school and life as a whole. The other part, the one we don't know anything about, that part is left unfinished.

The father in this example further explained that it was 'extremely important' that the memorial stone was personal, since it was such a young person that had died. Similarly, Francis et al. (2005, p. 172-7) notice in their studies of some London cemeteries that parents tending to the graves of their children felt a strong need to show the world what their child had been like. This was especially important when the child had died very young (Francis et al., 2005, pp. 172-5). Additionally, by constructing an identity for their deceased child the bereaved parents in Francis et al.'s study also seemed to be constructing an identity for themselves as caring and protective parents (2001, pp. 228-9; 2005, p. 174).

The landscape and placement of the gravesite for another deceased boy in Petersson's studies reflects both the bereaved mother's and the departed's preference for nature and vitality. Down by the water in a forest cemetery lays a memorial in the form of a natural stone, behind it a wooded slope where light filters through the trees in the evening. There are many birds in the area and on the water boats can occasionally be seen fishing for Baltic herring. The liveliness and scenery of the site are much appreciated by the bereaved but, as she said, 'It is very hard to know what is right. If it really is [his] needs or our needs, but I like water and I like woods and he liked water and he liked woods'. As material for the memorial stone the mother first wanted a specific stone on which her deceased son used to sit and rest when playing field hockey. But the shape of it was not right and it would have been hard to place text on the stone. Instead she found another natural stone that reminded her of a pillow. The site of the grave is decorated with flowers, stones, jewellery and other things that the interviewed mother brings home from travelling abroad. For the 
bereaved it is important to maintain these 'rituals', [7] as she calls them, of buying or collecting things for her deceased son since, as she puts it, 'You want to give your child things. I want to give [him] things.'

To buy, collect and give things to the deceased reflects a care that continues even after death (Petersson, 2009a, pp. 81-3). This need for continuing the care of a loved one is obvious in all of the interviews with people bereaved by traffic accidents in Petersson's study. It is also evident in a study of the practice of placing things in the open casket when saying goodbye (Aggedal, 2006, pp. 67-8), and it seems particularly urgent when the deceased is a child.

To select the stone and the material environment of the cemetery and design the memorial so that it suits the deceased's personal preferences could also be seen as an expression of this type of continuing care and protection for the departed (Francis et al., 2005, pp. 172-6) [8]. In an illustrative example from Petersson’s study, it was important for the mother of a deceased young woman to leave a little earth collected from the land where her daughter was living when she died in a car crash. She said her daughter had felt more at home there than in her native country. Each time the bereaved mother goes to this land she brings back a pebble or a shell from the beach to place on her daughter's grave. When choosing a site for the grave, which leys in the same churchyard as the church where the deceased was baptised, it was also crucial to the mother that it have a tree, since her daughter did not like the sun but always wanted to lie in the shade of a big tree. And, as the interviewed mother said, 'It should be the largest, the highest tree since she was the best!'

The memorial for the young woman is made of a natural stone from the county in which the bereaved mother was born, and she describes it as round and smooth with a little indented hole on one side. The surface of the stone has a pattern that she 
says resembles clouds - a pattern that resonated with the fact that the family had already decided to engrave three little birds on the stone in memory of the young woman's favourite song by Bob Marley. When the urn with her cremated remains was buried, her bereaved mother also laid down a handkerchief the she had been given at her confirmation along with some perfume and a lucky clover to wear around her neck.

Selecting the material environment of the cemetery to suit the deceased's preferences, as in the examples above, can be a way for the bereaved to find comfort and peace of mind by ensuring that even the gravesite, the last place that they will ever plan and prepare for their child, is a nice place for the departed. Similarly, in his study of the social world of the cemetery, Bachelor (2004, p. 168) describes how people construct ideal metaphysical worlds in which they envisage the deceased (see also: Aggedal, 2006, pp. 71-3), such as a children’s heaven with a fun playground. However, the actual existence of this metaphysical world is not important, Bachelor asserts; it should rather be seen as a way for the bereaved to find comfort and solace. Or, as one distressed grandmother in Bachelor's studies puts it, 'That's how I comfort myself. I don't think about whether it’s true or not' (Bachelor, 2004, p. 168).

In the same way, the bereaved people described in our text may not actually believe that the deceased will ever experience the memorial place they have so carefully prepared. The design and selection of a site for the grave that would suit the departed should rather be seen as a way for the bereaved to find comfort and solace by doing everything they can to protect their loved one. It is not surprising that this is especially evident when the deceased is a child tragically and unexpectedly killed in a traffic accident. The feeling of guilt and sorrow at not having been there at the time of 
the accident to comfort and say goodbye must at times be unbearable for the bereaved.

In addition, the bereaved mother in the example above uses both the material of the memorial stone and the gifts at the grave to tie her own past together with her deceased daughter's, strengthening the bond between them by keeping their common origin and kinship alive (Francis et al., 2005, pp. 141-78) [9]. A variation of this can be found in one of the other examples previously cited in which the mother selects the scenery for the gravesite to reflect both her and her son's preference for nature and vitality. By doing these things and making these choices the bereaved mothers not only make their deceased children a part of their present lives, they also reflect and realize their own self-image as well as expressing (and perhaps revising) the personality of the deceased (Reimers, 1999, p. 148; Francis et al., 2001, p. 227).

\section{Materiality: Representation and Presence}

In her examination of what she calls 'melancholy objects', building on Freud's work Mourning and Melancholia ([1917] 1960) as well as Winnicott's studies of transitional objects ([1971] 2005), Gibson (2004) suggests that we cannot remember the deceased as a pure spirit in immaterial abstraction. Material things, she asserts (p. 293), are not only associated with the deceased, they are part of their very being. According to Gibson (2004, p. 288), melancholy objects, like the sweater of a loved one or a photograph of a deceased friend, have an existential dimension in that they not only mediate between 'I' and 'you', 'self' and 'other', 'here' and 'there', but also act as materialised stand-ins for our experience of the gap between these states. Hence melancholy objects, just like transitional objects such as children's teddy bears, dolls 
and other comforting toys, function by both materialising and locating absence and loss (Gibson, 2004, p. 288).

The act of placing personal memorial items associated with the lost loved one, such as toys, on the grave may be seen as a symbolical and ritual tool that facilitates a tangible connection between what Åkesson (1997) calls the 'symbolic' and 'diabolic' realities, where the phrase ‘symbolic reality’ stands for experiences of unity and meaning in life, whereas ‘diabolic reality’ denotes conceptions of life as disruptive and meaningless (Åkesson, 1997, pp. 112-13, 149-50; Petersson 2009a, p. 83). A telling case in point from Petersson's study is the grave of a young man who died in a car crash: the memorial stone, on which his name is engraved in his own handwriting, stands next to pebbles collected at the site of the fatal accident. The memorial stone and the pebbles bring together the past and the present, life and death, the symbolic and diabolic realities.

The material things and practices described in this text can also be seen as giving the deceased a form of presence by imparting memory to the gravesite and giving it a certain meaning (Petersson 2009a, p. 82; 2009b, p. 135). Memorial items, and perhaps particularly the memorial stone, help us recall and feel the presence of the deceased. Francis et al. (2005, p. 124) even state that the hard stone material of the memorial may be a metaphor for the 'enduring' bones of the deceased, whereas the ephemeral flowers placed on the grave symbolize the more transient flesh. By tending to the memorial stone and decorative plantings, 'the body - bones and flesh - is symbolically reconstructed, and thereby the identity, personhood and memory of the deceased, so closely associated with the physical self' (Francis et al., 2005, p. 124). With these memorial representations and material items, as Gibson notes (2004, p. 
291), 'the transitional nature of human corporeal existence is both compensated for and replaced'.

Similarly, Francis et al. (2005, p. 124) maintain that for many of the bereaved in their studies the memorial stone 'is' the departed, a feature the authors say comes from the marker's proximity to the bodily remains. Another type of proximity, based on the relation between a stone and a living body, can be found in the previously cited example of the mother who wanted to mark her son's grave with the very stone on which he used to sit and rest when playing field hockey. In a third example, taken from the research project 'Designing Places for Memory and Meaning in the Contemporary Urban Landscape’ (LTJ-Fakulteten, Alnarp, 2009) [10], the relation between the body of a young boy killed in a motor vehicle accident and the memorial stone on his grave is based on similarity rather than proximity: the stone is sculpted to resemble a photograph of the departed taken shortly before his death. The sculptor of the memorial recounts that the bereaved family members often embrace the stone when visiting the boy’s grave [11].

However, the important thing in the examples above is not the distinction between similarity and proximity, but rather the way which some material things, through their resemblance with or proximity to the deceased, may bring about a social encounter with the presence of the absent. Brown's (1981, p. 88) interpretation of the religious notion of praesentia, linked to the way saints are believed to be present in their absence through icons, relics and holy places (Petersson, 2004, pp. 111-9; 2009b, p. 140), could perhaps be seen as a social anthropological case in point. A similar focus, though with an emphasis on the moral encounter with the presence of the absent, is to be found in Lévinas’s (1987, p. 116) philosophical text on language and proximity, which traces the phenomenological grounds of religious ritual and 
kerygmatic language back to the touch and the caress (Petersson, 2004, pp. 116-9; 2009a, pp. 81-3; 2009b, pp. 140-1).

In his article on place, touch and praesentia, Hetherington (2003, p. 1937) explains praesentia as 'both a form of the present and a form of presencing something absent'. To touch something is also to be closer to and more engaged in what one is experiencing than merely looking at it. Additionally, 'We are often touched by what we touch - a lover's body, a child's hand ... or a sculpture [...] a set of rosary beads in a pocket perhaps’ (Hetherington, 2003, p. 1936).

Just as a piece of clothing from a deceased loved one can somewhat compensate for the familiar smell and touch of the person lost (Gibson, 2004, pp. 2889), to care for, touch or even hug the memorial stone may perhaps in some way compensate for, materialise, and locate the immateriality and absence of the deceased. Also, by leaving an empty space on a memorial stone representing her dead son’s unfinished life, one bereaved mother in Petersson's study both materialises and locates her lost future memories of the deceased, hence creating a form of presence of a time that will never come.

\section{Designing a Public Memorial Place}

In the previous sections of this text we examined the importance for bereaved people who unexpectedly had lost a child or a spouse in a traffic accident of designing the memorial stone and gravesite so that they represent the deceased. In this examination the very materiality of the memorial stone and location of the site of the grave were held as crucial for the notion of materialising and locating feelings of grief and loss and for creating a continuing link between the bereaved and the deceased. 
Communicative, spatial and physical values are important also in the design of more public and common commemorative landscapes (Hunt, 2001). Even though the context, scale and design process of for instance a public monument differ from that of the individual memorial place in the cemetery. Commemoration through a public monument usually only arises when the death is considered to be a societal, national, or even international matter. Examples of such cases are when someone who has significance for society dies or when a large number of people die simultaneously.

When creating a public memorial place design professionals are often brought into the process of shaping a common environment for grief. As Foote ([1997] 2003, pp. 341-4) notes, it is often difficult for the designer of a public monument to satisfy both the bereaved individual and the common feelings of grief shared by a city, a society or a nation. The clash between privacy and exposure in public space can also be problematic from an authoritative as well as a personal point of view (see, among others: Azaryahu, 1996; Burk, 2003; Petersson, 2010) [12]. There may further be both practice-based and communication-based difficulties due to the everyday setting of some common urban memorial places, as where the space of death and grief, conveyed by the memorial itself and the memorial items left at the site, collides with the busy space of roads, sidewalks and bicycle paths (Petersson 2009a, p. 80; 2009b, p. 136).

\section{Memory Objects and Passage Landscapes}

For designers confronting such physical, spatial and communicative issues, the concepts of memory object and passage landscape, developed over years of professional practice in landscape architecture (Wingren, 2002) and in an academic 
doctoral thesis (Wingren, 2009), can be useful. These terms should be seen as theoretical and practical tools that may be applied by landscape architects to deal with questions of how a landscape can be designed to conceptualise and communicate the different functions and experiences that it contains.

Wingren (2009, pp. 187-8) has applied the term passage landscape to landscapes that contain different states of velocities, directions and presence at the same time. Road landscapes, for example, contain various experiences of being on or beside the road, travelling fast or slowly, in one direction or the other (Wingren, 2009, p. 187). All of these spatial and experiential factors have an importance for how the landscape is conceived and interacted with, for instance in the case of how roadside memorials are experienced (Juhlin and Normark, 2008, p. 387).

The departure point for the term passage landscape is for Wingren the memorial garden Fossar de la Pedrera at Montjuïc in Barcelona, built in 1986 and designed by the architect Beth Galí for the thousands of people that were executed during the Franco regime. The memorial garden is located in a quarry once used as a mass grave for the regime's victims. The entrance to the memorial site is arranged as a physical passage with winding stairs and a 'filtering zone' made of cypress trees and pillars with memorial inscriptions to the deceased. According to Wingren, this entrance functions as a passage landscape, giving visitors time to switch from one state of mind to another on their way into the former quarry. Passage landscapes can thus be said to physically support 'threshold rites' like the rites of passage (van Gennep, [1909] 1960, pp. 146-65; Turner, [1967] 1970, pp. 93-110) in which the ritual subject crosses over from one state to another (Petersson, 2004, pp. 60-4) [13].

The term memory object is for Wingren (2009, pp. 188-90) a concept that reveals how a thing may be designed and situated in a landscape in order to become a 
narrative object - one that allows a visitor to interpret, understand, and experience the history and identity of the landscape in a specific way. As an example, the cypress trees, which are often associated with places of death, and the memorial inscriptions on the pillars in the entrance to the cemetery of Fossar de la Pedrera may be seen as memory objects in Wingren's use of the term, telling the story of the deceased and the history of the fatal place as well as guiding the visitor into the memorial garden and bridging the gap between the outside and the inside of the memorial place.

\section{Examining the Public Monument at Backaplan, Gothenburg}

In order to give a recent example of a complex passage landscape with powerful memory objects, we will now discuss the design process and selection of the site for the public monument inaugurated on October 29, 2008 in remembrance of the sixtythree young people who died in a fire at a dance club in Gothenburg, Sweden in 1998. The study of this memorial place was made in 2008/2009 within the research project 'Designing Places for Memory and Meaning in the Contemporary Urban Landscape' (see endnote 10) and includes an interview with the artist Claes Hake, interviews with representatives from the municipality of Gothenburg, and an interview with the president of the relatives association BrandOffrens Anhöriga (BOA) as well as questionnaires addressed to people bereaved by the fire [14].

The data used in this text is taken from an interview by Jallow, Lieberg and Sörensen with Lars Lilled, who is the head of development at the social welfare service of Gothenburg and worked as coordinator after the fire, and Bjarne Pettersson, consultant with several commissions in connection to the catastrophe of the fire. We have also used data from an interview by Wingren, documented by Jallow, with Claes 
Hake who designed the public monument as well as from a questionnaire by Lieberg and Sörensen on the memorial place at Backaplan and the gravesite in the cemetery, distributed to people bereaved by the fire through BOA [15].

The siting of the monument at Backaplan was influenced by the location of a spontaneous memorial created in a parking lot in front of the burned-out club shortly after the fire. According to Lilled, the city of Gothenburg was sensitive already from the start to the importance this spontaneous memorial place held for the bereaved, and they arranged to purchase the space occupied by the memorial from the private owner of the parking lot. For a ceremony held six months after the fire, the city commissioned a temporary memorial for the site in the form of a blue bench on which the bereaved could leave mementos.

After this ceremony, and with the consent of the bereaved, the memorial objects accumulated on the site were relocated to the Gothenburg City Museum. The fresh flowers were composted and the soil was later used to plant two memorial trees, chosen by Hake, beside the public monument. Out of the melted candles collected at the spontaneous memorial, nuns from Vadstena Convent moulded sixty-three new candles that are kept in display cases inside the now restored club together with things found after the fire, including burnt shoes and a mobile phone belonging to one of the victims.

In the decade that passed from the fire to the final inauguration of the public monument, a design process evolved that included both the City of Gothenburg and the bereaved, states Lilled. The victims of the fire included people from nineteen nations, and in the days after the fire the bereaved formed several relatives' associations based on their different nationalities, religions, and cultures (see also Nieminen Kristofersson 2002: 165-78) [16]. Initially, these relatives’ associations 
came up with several different suggestions for the design of the monument. But, asserts Lilled, the city soon made it clear that in order to not favour one group over the others it would hold a competition among invited artists to design a common monument. One year after the fire a single common relatives' association, BOA, had formed to represent all of the bereaved, and it has been active in the decision to convert the burned-out club into a memorial hall and in choices relating to the public monument and memorial place outside the hall. The artists' competition proposals were exhibited both in the restored memorial hall and at the Gothenburg City Museum. The final choice of Hake’s scheme was made by the City of Gothenburg with the consent of BOA.

The public monument, located near the spot of the original spontaneous memorial, is situated in the midst of a busy thoroughfare for pedestrians and cyclists. To deal with this issue, Hake at first wanted the red quartzite stone used to pave the bike path that passes by the monument to be ribbed like a sea bed shaped by waves. As it crossed through the passage landscape of the memorial, the red-ribbed bike path would serve as a memory object to call cyclists' attention to the fact they were passing a place that was something out of the ordinary. Unfortunately the idea was rejected out of concern for the cyclists' safety, and the path was paved smooth instead - with red quartzite that actually lay at the bottom of the sea some million years ago.

The monument itself consists of several sections of slightly bent and polished slabs of dark grey kyanite stone, shimmering in blue, forming the shape of a protecting wall with the names and ages of the victims engraved in gold. In front of the memorial wall lays a huge flat stone, highly polished to reflect the sky, for the bereaved to leave fresh flowers and lighted candles on. Next to the monument are planted two memorial trees, weeping-willow-leafed pear trees, commonly known as 
the olive trees of the north. Behind the monument the artist decided to plant a fragrant honeysuckle, whose flower symbolises the province to which the city of Gothenburg belongs.

\section{[Insert figure 1 here]}

The monument to sixty-three young people who died in a fire at a dance club in 1998 at Backaplan, Gothenburg. Photographer: Mats Lieberg.

According to Lilled, the public monument at Backaplan is a collective memorial place where common feelings of loss and grief can be shared and dealt with whereas the individual grave in the cemetery is a more private memorial place. These different functions of various memorial places are noticeable also in Petersson's (2010) study, where for instance fresh flowers are left at roadside memorials by unknown community members whereas the site of the grave in the cemetery is a memorial place for the closest family of the deceased.

Several of the bereaved in Lieberg's and Sörensen’s questionnaire describe the fatal place where the deceased's lives were lost as 'a gate to the deceased' while another claims that it is a place on which 'their souls are engraved'. For these bereaved respondents, the grave does not have this same meaning. The experience of some kind of presence of the deceased at the accident site or attached to things found at the fatal scene is also to be found in studies of roadside memorialisation (Hartig and Dunne, 1998, pp. 17-8; Petersson, 2004, pp. 109-10; Clark and Franzmann, 2006, pp. 588-91; Petersson, 2009a, pp. 81-3; 2009b, pp. 135, 140-1; Klaasens at al., 2009, p. 197) [17].

A third informant responding to Lieberg's and Sörensen's questionnaire explains the meaning of the memorial place at Backaplan with these words:

The punctuation mark [the monument] means closure, but also the beginning of a new sentence, an important punctuation mark that gives structure, the right construction of the sentence and context. The place shows when, where, how and whom, something which all passers by can get an understanding of. Human beings get tattoos to mark important 
events in their lives that they need and want to remember, not only in thoughts but also something concrete [and] symbolic, something that one can touch and see in front of oneself, not only for the present but also for the future. The dark memorial stone is a tattoo that Backaplan wears on its arm.

The dark stone wall with the names and ages of the victims in gold, the red pavement, the memorial trees and honeysuckle planted at the site, and the natural stone reflecting the sky all function in different ways as important memory objects in the passage landscape of the site. These memory objects tell the story of a disaster that affected not only the closest relatives of the victims but the entire city of Gothenburg. Though the engraved names of the victims suggest the ethnic diversity that separated them, the repetition of their young ages emphasizes the universal tragedy of their loss.

Furthermore, the sixty-three names on the monument and the sixty-three new candles kept in the room where the fire took place not only represent the individual personal tragedy and the common feelings of loss shared by the bereaved, they also link the place of death inside the meeting hall to the new memorial place outside it. By bridging to the past to support the regeneration of present memories, they also aid the construction of future ones.

\section{Conclusions}

Although the context, scale and design process differ between memorial stones, marking the site of the individual grave, and public monuments, telling the history of a common fatal event, we have in this text fore fronted representation, materiality and presence as important qualities for locating and materialising feelings of grief and loss and enabling a continuing link between the bereaved and the deceased. We have stressed the significance of a memorial place communicative, spatial and physical values, for bereaved people designing the memorial stone and gravesite to express 
something about the deceased, as well as to the professional's design of a public

monument, expressing shared feelings of grief and loss as well as individual

bereavement. These are the tools for constructing memorial places that bridges

between the space of life and the space of death, not only by serving as places for

storing the past but also by supporting the regeneration of present memories and the

construction of future ones.

\section{Acknowledgements}

We would like to thank Jan-Olof Aggedal for serving as an opponent of this text at a seminar held at the Department of Architecture and Built Environment, Lund University, on March 18, 2010. We also want to thank the other members of the research group 'Designing Places for Memory and Meaning in the Contemporary Urban Landscape’: Ann-Britt Sörensen, Mats Lieberg and Sabina Jallow, as well as Petersson's supervisors Lars-Henrik Ståhl and Gunnar Sandin.

\section{Notes}

1. One reason for this may be the new and more liberal Swedish burial law of 1990, which gives the owner of the grave greater freedom than before to determine the appearance of the memorial stone and gravesite (Begravningslag, 1990:1144, §§ 25-9).

2. The phenomenon of recent roadside memorialisation in Sweden seems to have developed over the last twenty to twenty-five years even though earlier occasional cases as well as similar precedent practices can be found (Petersson 2009a).

3. The search for interviewees was conducted with the help of an informative letter which explained the survey as well as asked for volunteers. The letter was sent to the trade union papers Akeri \& Transport and Svenska Transportarbetareförbundets medlemstidning, which published the content of the letter at the end of April in 2005, and to the workplaces Taxi Kurir in Malmö, Taxi Skåne in Lund, Sanofi-Aventis in Lund, the Swedish Road Administration in Malmö, Kristianstad and Gothenburg, and to the organisation MADD Sweden. In the group with people bereaved by traffic accidents four persons out of six where found through MADD Sweden and two persons were contacted through friends and relatives.

4. All quotations in this text are Petersson's own translations of the respondents' original Swedish.

5. For different types of bereavement see: Klass et al, 1996; Francis et al., 2005, pp. 141-78.

6. For a discussion of the cultural construction of different forms of dying as 'good' or 'bad' see: Seale and Van der Geest, 2004; for models of the 'good' death and 'good' grief see: Walter, 1996, pp. 109-20; and for the construction of 'good' death see: Valentine, 2008, pp. 40-72.

7. The ritual activities revealed in the interview material have been discussed in other texts (Petersson, 2009a; 2009b; 2010) and will not be further explored in this article.

8. For other decisions affecting the bereaved's selection of a site of the grave, see: Sörensen, 2009.

9. Memorial practices like these also reflect a relatively new approach to mourning in modern Western society, which reveals a way of living with grief by creating new relations and 'continuing bonds' to the deceased instead of trying to seek and end to mourning by letting go of the past (Klass et al., 1996; Hallam et al., 1999; Prendergast et al., 2006; Valentine, 2008).

10. The research project 'Designing Places for Memory and Meaning in the Contemporary Urban Landscape' is an interdisciplinary three-year research project, funded by the Swedish research council Formas, of which both Petersson and Wingren are members.

11. However, it is important to point out that in this particular example the bereaved do not see the memorial stone as the deceased boy; they see it as a sculpture with similar features. Personal communication at the workshop held as part of the research project 'Designing Places for Memory and Meaning in the Contemporary Urban Landscape' on November 5, 2009 at the University of Agricultural Sciences, Alnarp, Sweden.

12. Works that might be useful in a more general discussion of private and public space and practice include De Certeau’s ([1984] 2002) division between 'space’ and 'place’ and Lefèbvre’s 
([1974] 1991) three-part concept of 'representational space’, 'spatial practice’ and 'representations of space'.

13. One example of a rite of passage is the burial ceremony, which allows for the dead body to go through a purifying preliminal phase, an ambiguous liminal phase, and a reintegrating postliminal phase in which the corpse is let back into society when interred in the burial place at the cemetery (van Gennep, [1909] 1960, pp. 146-65; Turner, [1967] 1970, pp. 93-110).

14. The questionnaires were distributed through an upper secondary school, in which many of the deceased had been students, and through BOA.

15. The quotations in this section are Petersson's own translation of the respondents' original Swedish.

16. Initially, the arson committed was seen as a racist crime by the media as well as among people in the society where the fire took place. However, it later came to the fore that this was not the case (see: Nieminen Kristofersson, 2002, pp. 9-11).

17. In Lieberg's and Sörensen's study some bereaved hold the memorial place at Backaplan as more meaningful to them than the grave in the cemetery. In Petersson's study four out of six of the informants bereaved by road traffic accidents rated the grave as the main memorial place while the home memorial, or simply the home in general, was second; two out of six rated the home as the main memorial place and the grave second; the accident site was considered the least important by all of the bereaved (Petersson 2009a: 82, 2009b: 134-5). When estimating the intensity, importance and meaning of the various memorials places it is, however, important to note that memorial activity changes over time (Everett, 2000, pp. 101-2; Petersson, 2010).

\section{References}

Aggedal, J-O. (2006) En necessär i kistan - något om människors och kyrkans trostolkning i väntan på en större undersökning, in Göran Gunner (Ed.) På spaning - från Svenska kyrkans forskardagar 2005 (pp. 59-75). Stockholm: Verbum Förlag.

Andersson, G. (2004) Gravspråk som religiös strategi: Valsta och Skälby i Attundaland under vikingatid och tidig medeltid. Stockholm: Riksantikvarieämbetet.

Ariés, P. [1976] (1994) Western Attitudes Toward Death from the Middle Ages to the Present. Trans. P. M. Ranum. London \& New York: Marion Boyars.

Azaryahu, M. (1996) The spontaneous formation of memorial space. The case of Kikar Rabin, Tel Aviv, Area, 28(4), 501-13.

Bachelor, P. (2004) Sorrow and Solace: The Social World of the Cemetery. Amityville \& New York: Baywood Publishing Company.

Begravningslag (1990) Begravningslag (1990:1144). Retrieved, February 06, 2010 from: http://www.notisum.se/RNP/sls/lag/19901144.htm.

Brown, P. R. L. (1981) The Cult of the Saints: Its Rise and Function in Latin Christianity. London: University of Chicago Press.

Burk, A. L. (2003) Private griefs, public places, Political Geography, 22, 217-33.

Clark, J. \& Franzmann, M. (2006) 'Authority from Grief, Presence and Place in the Making of Roadside Memorials’, Death Studies, 30, 579-99.

Dahlgren, C. (2000) När döden skiljer oss åt... Anonymitet och individualisering i dödsannonser: 1945-1999. Stockholm: Databokförlaget AB.

Dahlgren, C. \& Hermansson, J. (2003) Kremation och spridning av aska: förändrade begravningsseder i Sverige under sent 1990-tal?, RIT Religionsvetenskaplig Internettidskrift, 6. Retrieved, March 13, 2006 from: http://www.teol.lu.se/rit/pdf/6/jh1.pdf.

De Certeau, M. [1984] (2002) The Practice of Everyday Life. New ed. trans. S. Rendall. Berkeley \& Los Angeles, California: University of California Press. 
Etlin, R. A. (1984) The Architecture of Death: The Transformation of the Cemetery in Eighteenth-Century Paris. Cambridge, Massachusetts \& London: The MIT Press.

Everett, H. (2000) 'Roadside crosses and memorial complexes in Texas', Folklore, 111, 91-103.

Foote, K. E. [1997] (2003) Shadowed Ground: America's Landscapes of Violence and Tragedy. UK: University of Texas Press.

Francis, D., Kellaher, L. \& Neophytou, G. (2001) 'The Cemetery: The Evidence of Continuing Bonds', in J. Hockey, J. Katz \& N. Small (eds.), Grief, Mourning and Death Ritual (pp. 226-36). Buckingham \& Philadelphia: Open University Press.

Francis, D., Kellaher, L. and Neophytou, G. (2005) The Secret Cemetery. Oxford: Berg.

Freud, S. [1917] (1960) 'Mourning and melancholia', in The Standard Edition of the Complete Psychological Works of Sigmund Freud XIV (pp. 243-58). Trans. J. Strachey. London: Hogarth Press.

Gibson, M. (2004) 'Melancholy Objects', Mortality, 9(4), 285-99.

Gustafsson, G. (2003) När det sociala kapitalet växlas in: om begravningar och deltagandet i begravningar. Lund: Centrum för teologi och religionsvetenskap, Lunds Universitet.

Gustavsson, A. (2003) Gravstenar i Norge och Sverige som symboler för känslor, tankar och idéer i vår egen tid: en tilltagande individualitet under 1990-talet? Oslo: Novus.

Hagberg, L. (1937) När döden gästar. Svenska folkseder och svensk folktro i samband med död och begravning. Stockholm: Wahlström \& Widstrand.

Hallam, E., Hockey, J. and Howarth, G. (1999) Beyond the Body: Death and Social Identity. London: Routledge.

Hartig, K. V. \& Dunn. K. M. (1998) 'Roadside Memorials: Interpreting New Deathscapes in Newcastle, New South Wales’. Australian Geographical Studies, 36(1), 5-20.

Hetherington, K. (2003) 'Spatial Textures: Place, Touch and Praesentia'. Environment and Planning A, 35, 1933-44.

Hunt, J. D. (2001) “'Come Into the Garden Maud': Garden Art as a Privileged Mode of Communication and Identity', in J. Wolschke-Bulmahn (Ed.) Places of Commemoration: Search for Identity and Landscape Design (pp. 9-24). Washington, D.C: Dumbarton Oaks Research Library and Collection.

Juhlin, O. and Normark, D. (2008) 'Public Road Signs as Intermediate Interaction'. Space and Culture, 11(4), 383-408.

Klaasens, M., Groote P. \& Huigen, P. P. P. (2009) 'Roadside Memorials from a Geographical Perspective’. Mortality, 14(2), 187-201.

Klass, D., Silverman, P. R. \& Nickman, S. L. (1996) Continuing Bonds: New Understandings of Grief. London \& Philadelphia: Taylor \& Frances.

Larsson, E-M. (2009) Muslimska begravningsplatsen i Malmö - förändring över tid, Sveriges Lantsbruksuniversitet, Fakulteten för Landskapsplanering, trädgårdsoch jordbruksvetenskap. Retrieved, May 20, 2009 from: http://stud.epsilon.slu.se/139/1/larsson_e_090504.pdf.

Lefèbvre, H. [1974] (1991) The Production of Space. Trans. D. Nicholson-Smith. Oxford, UK \& Cambridge, USA: Blackwell.

Lévinas, E. (1987) Collected Philosophical Papers. Trans. A. Lingis. Dordrecht, Boston \& Lancaster: Martinus Nijhoff Publishers. 
Lindahl, G. (1969) Grav och Rum: svenskt gravskick från medeltiden till 1800-talets slut. Stockholm: Almqvist \& Wiksell.

LTJ-Fakulteten, Alnarp. (2009) Utveckling och gestaltning av minnesplatser i nutida stadsmiljö. Retrieved, February 06, 2010 from: http://www.ltj.slu.se/6/O6_for_1.html.

MADD Sweden. Retrieved, March 10, 2005 from: http://www.madd.se/.

Nieminen Kristofersson, T. (2002) Krisgrupper och spontant stöd: om instatser efter branden i Göteborg 1998, PhD-diss. Lund Dissertations in Social Work, 7. Lund: Socialhögskolan, Lunds Universitet.

Petersson, A. (2004) The Presence of the Absent. Memorials and Places of Ritual, PhLic diss. Lund: Department of Architecture, University of Lund.

Petersson, A. (2009a) 'Swedish Offerkast and Recent Roadside Memorials', Folklore, 120, 75-91.

Petersson, A. (2009b) 'The Altar of the Dead: A Temporal Space for Memory and Meaning in the Contemporary Urban Landscape', in S. Bergmann, P. Scott, M. Jansdotter, \& H. Bedford Strohm (Eds.), Nature, Space and the Sacred: Interdisciplinary Perspectives (pp. 131-44). Surrey: Ashgate.

Petersson, A. (2010, forthcoming) 'The Production of a Memorial: Materialising Expressions of Grief', in A. Maddrell \& J. Sidaway (Eds.), Deathscapes: Places for Death, Dying and Bereavement. Ashgate.

Prendergast, D., Hockey, J. and Kellaher, L. (2006) 'Blowing in the wind? Identity, materiality and the destination of human ashes', Journal of the Royal Anthropological Institute, 12, 881-98

Reimers, E. (1999) 'Death and Identity: Graves and Funerals as Cultural Communication', Mortality, 4(2), 147-66.

Seale, C. \& Van der Geest, S. (2004) 'Good and Bad Death: Introduction', Social Science and Medicine, 58(5), 883-5.

Silverman, P. R. \& Nickman, S. L. (1996) 'Concluding Thoughts', in D. Klass, P. R. Silverman, \& S. L. Nickman (Eds.), Continuing Bonds: New Understandings of Grief (pp. 349-55). London \& Philadelphia: Taylor \& Frances.

Sörensen, A-B. (2009) Att välja gravplats. Retrieved, February 9, 2010 from: http://www.ltj.slu.se/PDF/Att\%20valja\%20gravplats_ABS.pdf

Turner, V. ([1967] 1970) The Forest of Symbols: Aspects of Ndembu Ritual. Ithaca: Cornell University Press.

Valentine, C. (2008) Bereavement Narratives: Continuing Bonds in the Twenty-first Century. London and New York: Taylor \& Frances.

Van Gennep, A. ([1909] 1960) The Rites of Passage. Trans. M. B. Vizedom \& G. L. Caffee. Chicago: The University of Chicago Press.

Walter, T. (1994) The Revival of Death. London \& New York: Routledge.

Wingren, C. (2002) Göteborgsregionens infarter: ett samarbetsprojekt mellan Vägverket och de fem kommunerna Ale, Göteborg, Härryda, Mölndal och Partille. Göteborg: Vägverket region väst.

Wingren, C. (2009) En landskapsarkitekts konstnärliga praktik - kunskapsutveckling via en självbiografisk studie. PhD diss. Alnarp: Department of Landscape Planning, Swedish University of Agricultural Sciences.

Winnicott, D. W. [1971] (2005) Playing and Reality. New ed. London: Routledge. Åkesson, L. (1997) Mellan levande och döda: föreställningar om kropp och ritual. Stockholm: Natur och Kultur: Forskningsrådsnämnden. 


\section{Figure captions}

Figure 1. The monument to sixty-three young people who died in a fire at a dance club in 1998 at Backaplan, Gothenburg. Photographer: Mats Lieberg. 